Number 4

\title{
PERBEDAANZONA HAMBAT PERTUMBUHAN Staphylococcus aureus PADA BERBAGAI KONSENTRASI REBUSAN DAUN SALAM (Syzygium polyanthum) SECARA IN VITRO
}

\author{
Luh Kadek Suciari ${ }^{1}$, Nyoman Mastra ${ }^{2}$, Cok. Dewi Widhya $\mathrm{HS}^{3}$
}

\begin{abstract}
Background Staphylococcus aureus isone of causes infection and this bacteria have been resistence for many antibiotic. Bayleaf have antibacterials substance, which stew leaves can be treat infection caused Staphylococcus aureus. The purpose of this study was to determine differences in growth inhibition zone of Staphylococcus aureus at various concentrations of water stew of bay leaf.

Method The method of this study is true experiment with posstest only control design, and used Kirby Bauer disk diffusion method with various concentrations of water stewed of bay leaf $(20 \%, 40 \%, 60 \%, 80 \%, 100 \%)$, positive control (chloramfenicol $30 \mu \mathrm{g}$ ) and negative control (sterile distilled water).

Result The result showed that the average diameter of inhibition zone in concentration 20\%, $40 \%, 60 \%, 80 \%$, and $100 \%$ is $7 \mathrm{~mm}, 8,4 \mathrm{~mm}, 9,6 \mathrm{~mm}, 10,5 \mathrm{~mm}$ and 11,5 mm. Based on statistical analysis using oneway ANOVA available the value of $p(0,000)<\alpha(0,05)$, so the inhibition zone is significant difference of growth inhibition zone of Staphylococcus aureus at various concentrations of stewed water bay leaf.

Conclusion Water stew of bay leaf can inhibit the growth of Staphylococcus aureus, and there are differences in growth inhibition zone of Staphylococcus aureus at various concentrations of water stew of bay leaf.
\end{abstract}

Keywords: stew of bay leaf; Staphylococcus aureus; inhibition zone

\section{PENDAHULUAN}

Infeksi Saluran Pernapasan Akut (ISPA) merupakan infeksi akut yang menyerang salah satu atau lebih dari saluran napas mulai dari hidung sampai alveoli termasuk adneksanya (sinus, rongga telinga tengah dan pleura) ${ }^{1}$. Infeksi yang sering diakibatkan oleh masuknya kuman atau bakteri ke dalam tubuh manusia merupakan penyakit yang sering diderita di Negara berkembang seperti
Indonesia. Prevalensi ISPA di Indonesia mencapai 4,5\%, khususnya di Provinsi Bali pada tahun 2009 jumlah ISPA mencapai 52.960kasus, sedangkan di tahun 2010 kasus ini bahkan menyebabkan 1.967 pasien menjalani rawat inap di RSUD seBali akibat pneumonia. Peningkatan yang tinggi terjadi pula di tahun 2012, hingga mencapai 370.504 kasus $^{2}$. Pada tahun 2014, ISPA (Pneumonia) berada pada 
Luh Kadek Suciari, dkk., Perbedaan Zona Hambat Pertumbuhan Staphylococcus aureus Pada

Berbagai Konsentrasi Rebusan Daun Salam (Syzygium polyanthum) Secara In Vitro

urutan kesembilan setelah penyakit Pulpa dan jaringan periapikal ${ }^{3}$. Pneumonia oleh bakteri dapat disebabkan oleh Staphylococcus aureus. ${ }^{4}$

Staphylococcus aureus merupakan bakteri patogen utama untuk manusia.Selain menginfeksi saluran pernapasan, bakteri Staphylococcus aureus dapat menyebabkan berbagai jenis infeksi antara lain infeksi pada kulit seperti bisul dan furunkulosis, hingga meningitis, infeksi pada saluran urin, dan juga endokarditis ${ }^{5}$.Staphylococcus merupakan anggota flora normal kulit, saluran napas serta saluran cerna manusia, mukosa mulut dan faring, saluran cerna hinggs rektum.Flora normal atau mikrobiota normal yang terdapat pada tubuh berperan sebagai lini pertahanan pertama menghadapi patogen mikroba, membantu pencernaan, berperan dalam degradasi toksin, dan berkontribusi dalam pematangan sistem imun ${ }^{6}$.

Pengobatan utama dalam penatalaksanaan penyakit infeksi dilakukan dengan pemberian antibiotika.Penggunaan antibiotik yang tidak tepat dapat menimbulkan dampak negatif, seperti terjadinya resistensi bakteri terhadap antibiotik.Staphylococcus aureustelah mengalami resistensi terhadapantibiotik oksasilin $40 \%$, vankomisin 40\%, klindamisin 50\% dan levofloksasin $50 \%{ }^{7}$.

Dalam upaya mengurangi konsumsi antibiotik pada penanganan penyakit dan menghindari terjadinya resistensi obat, maka penulis tertarik menggunakan bahan alam berupa daun salam sebagai antibiotik alami. Hasil penelitian mengenai uji sensitivitas ekstrak etanol daun salam terhadap pertumbuhan bakteri Staphylococcus aureus secara in vitro dengan variasi konsentrasi ekstrak $20 \%, 40 \%, 60 \%, 80 \%$ dan $100 \%$, diperoleh hasil bahwa semua konsentrasi dapat menghambat pertumbuhan bakteri Staphylococcus aureus ${ }^{8}$.

Berdasarkanuji pendahuluan yang penulis lakukan, terbentuknya zona hambat pada rebusan daun salam dapat memberikan pengaruh pada pertumbuhan bakteri Staphylococcus aureus.Daunsalam mengandung minyak atsiri, sitral, eugenol, tanin, dan flavonoida 9 . Sehinggaberdasarkan uraian di atas, penulis tertarik meneliti perbedaan zona hambat pertumbuhan bakteri Staphylococcus aureus pada berbagai konsentrasi rebusan daun salam(Syzygium polyanthum)secara in vitro. Perbedaan penelitian ini dengan penelitian lainnya yaitu pada penelitian ini digunakanrebusan daun salam(Syzygium polyanthum) yang tidak mengalami penambahan pelarut 
Luh Kadek Suciari, dkk., Perbedaan Zona Hambat Pertumbuhan Staphylococcus aureus Pada

Berbagai Konsentrasi Rebusan Daun Salam (Syzygium polyanthum) Secara In Vitro

kimia lainnya seperti etanol ataupun metanol untuk mendapatkan senyawa aktif dari daun salam. Alasan penulis memilih rebusan daun salam, selain tidak adanya proses penambahan pelarut lain seperti etanol dan metanol, diharapkan juga pada aplikasinya sebagai antibiotik alami masyarakat dapatlebih mudah membuatnya. Penggunaan aquadest dalam pembuatan rebusan juga didasari karena tergolong pelarut yangmudah didapat,tidak berbahayaserta bersifat netral dan dapat melarutkan beberapa senyawa aktif yang terdapat pada daun salam.

\section{METODE}

Jenis penelitian yang digunakan adalah True-experimentaldengan desain Posttest only-control design ${ }^{10}$.Pengujian aktivitas antibakteri dilakukan dengan metode difusi cakram Kirby-Bauer yang dilakukan di Laboratorium Bakteriologi Jurusan Analis Kesehatan Kesehatan Politeknik Kesehatan Denpasar.Sampel dalam penelitian ini yaitu lima perlakuan konsentrasi rebusan daun salam yaitu $20 \%$, $40 \%, 60 \%$, $80 \%$ dan $100 \%$ dengan lima kali pengulangan dan dua kali replikasi.

Tahap penelitian dilakukan dengan pembuatan rebusan daun salam,penanaman bakteri Staphylococcus aureus pada media Mueller Hinton Agar. Kemudiandilanjutkan dengan penanaman masing-masing cakram yang mengandung berbagai konsentrasi rebusan daun salam dan kontrol positif (kloramfenikol 30 $\mu \mathrm{g}$ ) serta control negatif (aquadest steril). Zona hambat pertumbuhan Staphylococcus aureus yang terbentuk pada masingmasing konsentrasi rebusan dapat diamati setelah proses inkubasi selama 24 jam pada suhu $37^{\circ} \mathrm{C}$. Diameter zona hambat diukur menggunakan mistar dalam satuan millimeter (mm).

\section{HASIL DAN PEMBAHASAN}

\section{Hasil}

Hasil diameter zona hambat pada dua kali replikasi dan lima kali pengulangan dapat dilihat pada Tabel 1. Data yang diperoleh kemudian dilakukan analisis menggunakan uji statistik Kolmogorov Smirnov (KS).Berdasarkan hasil pengujian diperoleh nilai $p=0,264$. Apabila nilai ini dibandingkan dengan nilai $\alpha(0,05)$ yang digunakan, maka nilai $p$ $>\alpha(0,264>0,05)$, sehingga data tersebut berdistribusi normal.

Setelah data dinyatakan berdistribusi normal, selanjutnya dilakukan pengujian menggunakan uji One Way Anova dengan tingkat kepercayaan 95\%, diperoleh hasil nilai probabilitas $p$ $(0,000)<\alpha(0,05)$ yang menandakan adanya perbedaan zona hambat pertumbuhan Staphylococcus aureus pada berbagai konsentrasi rebusan daun salam. 
Luh Kadek Suciari, dkk., Perbedaan Zona Hambat Pertumbuhan Staphylococcus aureus Pada

Berbagai Konsentrasi Rebusan Daun Salam (Syzygium polyanthum) Secara In Vitro

Data kemudian diolah dengan uji nilai $p(0,000)<\alpha(0,05)$ yang LSD (Least Significant Difference) untuk menunjukkan ada perbedaan yang mengetahui perbedaan pada masing- significant antara masing-masing masing konsentrasi rebusan daun salam konsentrasi tersebut.

dalam menghambat pertumbuhan

Staphylococcus aureus.Berdasarkan hasil

uji LSD pada semua konsentrasi diperoleh

Tabel 1.Data Hasil Pengukuran Diameter Zona Hambat PertumbuhanStaphylococcus aureus pada Berbagai Konsentrasi Rebusan Daun Salam secara In Vitro

\begin{tabular}{cccc}
\hline \multirow{2}{*}{$\begin{array}{c}\text { Perlakuan } \\
\text { Konsentr } \\
\text { asi }\end{array}$} & \multicolumn{2}{c}{$\begin{array}{c}\text { Rerata Diameter Zona Hambat } \\
\text { Per Replikasi (mm) }\end{array}$} & $\begin{array}{c}\text { Rerata } \\
\text { Seluruh } \\
\text { Replikasi } \\
\text { (mm) }\end{array}$ \\
& I & II & \pm SD \\
\hline $20 \%$ & & & $7 \pm 0$ \\
$40 \%$ & 7,8 & 7 & $8,4 \pm 0,2$ \\
$60 \%$ & 9 & 9 & $9,6 \pm 0,2$ \\
$80 \%$ & 10 & 10,2 & $10,5 \pm 0,3$ \\
$100 \%$ & 11,2 & 11,8 & $11,5 \pm 0,3$ \\
Kontrol $(+)$ & 27,4 & 27,2 & $27,3 \pm 0,3$ \\
Kontrol $(-)$ & 0 & 0 & $0 \pm 0$ \\
\hline
\end{tabular}

\section{Pembahasan}

a. Kontrol

Kontrol positif yang digunakan dalam penelitian ini adalah kloramfenikol $30 \mu \mathrm{g}$. Pemilihan kloramfenikol sebagai kontrol positif didasari karena bakteri Staphylococcus aureus telah banyak mengalami resistensi terhadap beberapa antibiotik selain itu antibiotik ini bersifat bakteriostatik dengan spektrum luas yang aktif terhadap bakteri gram negatif dan gram positif, mampu menghambat perlekatan asam amino dari bakteri sehingga dapat menghambat pertumbuhan Staphylococcus aureus.
Berdasarkan diameter rerata yang diperolehdari kontrol positif,bila dibandingkan dengan tabel NCCLS, maka zona hambat yang terbentuk pada kloramfenikolberkategori sensitif yang berarti efektif menghambat pertumbuhan Staphylococcus aureus karena diameter yang terbentuk melebihi $18 \mathrm{~mm}$.Hasil pemeriksaan pada kontrol negatif (aquadeststeril) tidak menimbulkan adanya diameter zona hambat karena kandunganaquadest steril tidak memiliki senyawa antibakteri yang dapat menghambat pertumbuhan bakteri. 
Luh Kadek Suciari, dkk., Perbedaan Zona Hambat Pertumbuhan Staphylococcus aureus Pada

Berbagai Konsentrasi Rebusan Daun Salam (Syzygium polyanthum) Secara In Vitro

Tujuan pembuatan kontrol pada penelitian ini adalah untuk mengetahui adanya faktor-faktor yang berpengaruh terhadap diameter zona hambat seperti kualitas media yang digunakan dan terjadinya kontaminasi. Kloramfenikol sebagai kontrol positif digunakan sebagai pembanding untuk melihat zat uji yang diteliti sebaik zat kontrol yang digunakan atau tidak.Sedangkan aquadest steril sebagai kontrol negatif digunakan untuk mengetahui pengaruh aquadest yang digunakan dalam pembuatan rebusan daun salam terhadap pertumbuhan Staphylococcus aureus.

b. Konsetrasi $20 \%$

Berdasarkan kategori, diameter rebusan daun salam pada konsentrasi $20 \%$ ini memiliki kategori sedang sebagai antibakteri.Jika dibandingkan dengan kloramfenikol $30 \quad \mu \mathrm{g}$ sebagai kontrol positif maka diameter pada konsentrasi $20 \%$ ini tidak sebaik kontrol positif. Sedangkan bila hasil penelitian ini dibandingkan dengan hasil uji aktivitas antimikroba infusum daun salam terhadap pertumbuhan bakteri Escherichia coli pada konsentrasi $20 \%$ maka diketahui bahwa rebusan daun salam lebih baik daripada infusum, karena infusum tidak dapat menghambat pertumbuhan bakteri ${ }^{9}$. Hal ini dapat terjadi karena dalam proses pembuatan infusum, baik kualitas daun maupun proses pengeringan dapat menjadi faktor penentu terekstraksinya senyawa antibakteri yang terdapat dalam daun ${ }^{11}$.

c. Konsentrasi $40 \%$

Menurut ${ }^{11}$, diameter rebusan daun salam pada penelitian ini memiliki kategori sedang sebagai antibakteri. Namun jika diameter rerata zona hambat yang terbentuk pada konsentrasi $40 \%$ dibandingkan dengan diameter kontrol positif (kloramfenikol $30 \mu \mathrm{g}$ ) maka diameter pada konsentrasi ini tidak sebaik kontrol positif.

Berdasarkan hasil penelitian uji daya antibakteri ekstrak etanol daun salam dalam pasta gigi terhadap pertumbuhan Streptococcus mutans pada konsentrasi $40 \%$ diperoleh zona hambat sebesar7,73 $\mathrm{mm}^{12}$. Rebusan konsentrasi $40 \%$ pada penelitian ini memiliki diameter yang lebih besar $(8,4 \mathrm{~mm}>7,73 \mathrm{~mm})$ untuk menghambat pertumbuhan bakteri. Hal ini dapat terjadi karena walaupun kedua jenis bakteri yang digunakan merupakan gram positif namun terdapat perbedaan sifat dan sel penyusun bakteri. Sehingga hal ini dapat mempengaruhi penghambatan pertumbuhan dari kedua bakteri tersebut.

d. Konsentrasi $60 \%$

Konsentrasi rebusan daun salam $60 \%$ menunjukkan adanya peningkatan diameter dibandingkan dengan zona hambat yang terbentuk pada konsentrasi 
Luh Kadek Suciari, dkk., Perbedaan Zona Hambat Pertumbuhan Staphylococcus aureus Pada Berbagai Konsentrasi Rebusan Daun Salam (Syzygium polyanthum) Secara In Vitro

$20 \%$ dan $40 \%$. Rerata diameter zona hambat yang terbentuk pada konsentrasi $60 \%$ adalah 9,6 mm. Berdasarkankategori, diameter yang terbentuk pada konsentrasi $60 \%$ ini dikategorikan sedang sebagai antibakteri dan bila dibandingkan dengan kloramfenikol maka dinyatakan belum sebaik kloramfenikol sebagai kontrol positif. $^{11}$

Diameter zona hambat konsentrasi $60 \%$ pada penelitian ini lebih besar bila dibandingkan dengan diameter yang terbentuk pada penghambatan pertumbuhan jamur Aspergillus flavus ekstrak salam, rerata zona hambat pertumbuhan pada konsentrasi $70 \%$ diperoleh sebesar $8,06 \mathrm{~mm}^{11}$. Hal ini dapat terjadi karena perbedaan dinding sel penyusun antara jamur Aspergillus flavus dengan Staphylococcus aureus.

e. Konsentrasi $80 \%$

Rerata diameter zona hambat rebusan daun salam konsentrasi $80 \%$ adalah 10,5 $\mathrm{mm}$, diameter ini menunjukkan adanya peningkatan bila dibandingkan dengan zona hambat yang terbentuk pada konsentrasi 20\%, 40\% dan $60 \%$. Jika rerata diameter zona hambat yang terbentuk pada konsentrasi $80 \%$ dibandingkan dengan diameter kontrol positif (kloramfenikol $30 \mu \mathrm{g}$ ) maka diameter pada konsentrasi ini tidak sebaik kontrol positif, namun menurut Davis dan
Stout, diameter rebusan daun salam pada konsentrasi 80\% ini memiliki kategori kuat sebagai antibakteri. Pada penelitian ekstrak etanol daun salam terhadap pertumbuhan Staphylococcus aureus pada konsentrasi $100 \%$ diperoleh rerata zona hambat pertumbuhan bakteri sebesar $9,78 \mathrm{~mm}^{13}$. Jika hasil tersebut dibandingkan dengan diameter zona hambat konsentrasi $80 \%$ pada penelitian ini maka rebusan konsentrasi $80 \%$ memiliki kemampuan yang lebih baik dalam menghambat pertumbuhan bakteri Staphylococcus aureus. Hal ini dapat terjadi karena perbedaan daerah tumbuh tanaman salam, sehingga menyebabkan perbedaan kadar senyawa antibakteri yang terkandung.

\section{f. Konsentrasi $100 \%$}

Berdasarkan hasil pengukuran zona hambat pertumbuhan bakteri Staphylococcus aureus yang terbentuk pada media MHAdengan rebusan daun salam konsentrasi100\% menunjukkan diameter terpanjang bila dibandingkan dengan konsentrasi 20\%, 40\%, 60\%, dan 80\%. Data Tabel 1 menunjukkan rerata diameter sebesar $11,5 \mathrm{~mm}$.Jika diameter rerata zona hambat yang terbentuk pada konsentrasi $100 \%$ dibandingkan dengan diameter kontrol positif (kloramfenikol 30 $\mu \mathrm{g})$ maka diameter pada konsentrasi ini tidak sebaik kontrol positif, namun menurut Davis dan Stout, rerata diameter 
Luh Kadek Suciari, dkk., Perbedaan Zona Hambat Pertumbuhan Staphylococcus aureus Pada Berbagai Konsentrasi Rebusan Daun Salam (Syzygium polyanthum) Secara In Vitro

sebesar 11,5 $\mathrm{mm}$ yang terbentuk pada konsentrasi $100 \%$ ini memiliki kategori kuat sebagai antibakteri.

Pada penelitian ekstrak etanol daun salam terhadap pertumbuhan Candida albicans secara in vitro pada konsentrasi $100 \%$ diperoleh rerata zona hambat pertumbuhan sebesar $11 \mathrm{~mm}^{14}$. Jika hasil penelitian yang dilakukan tersebut dibandingkan dengan diameter zona hambat konsentrasi $100 \%$ pada penelitian ini maka diketahui bahwa pada konsentrasi yang sama diameter yang terbentuk pada rebusan daun salam memiliki zona hambat yang lebih besar.
Terbentuknya zona hambat ini terjadi karena adanya kandungan antibakteri yang terdapat pada rebusan daun salam. Berdasarkan Gambar 1, dapat dilihat bahwa semakin besar konsentrasi yang digunakan semakin besar diameter zona yang dapat menghambat pertumbuhan bakteri.

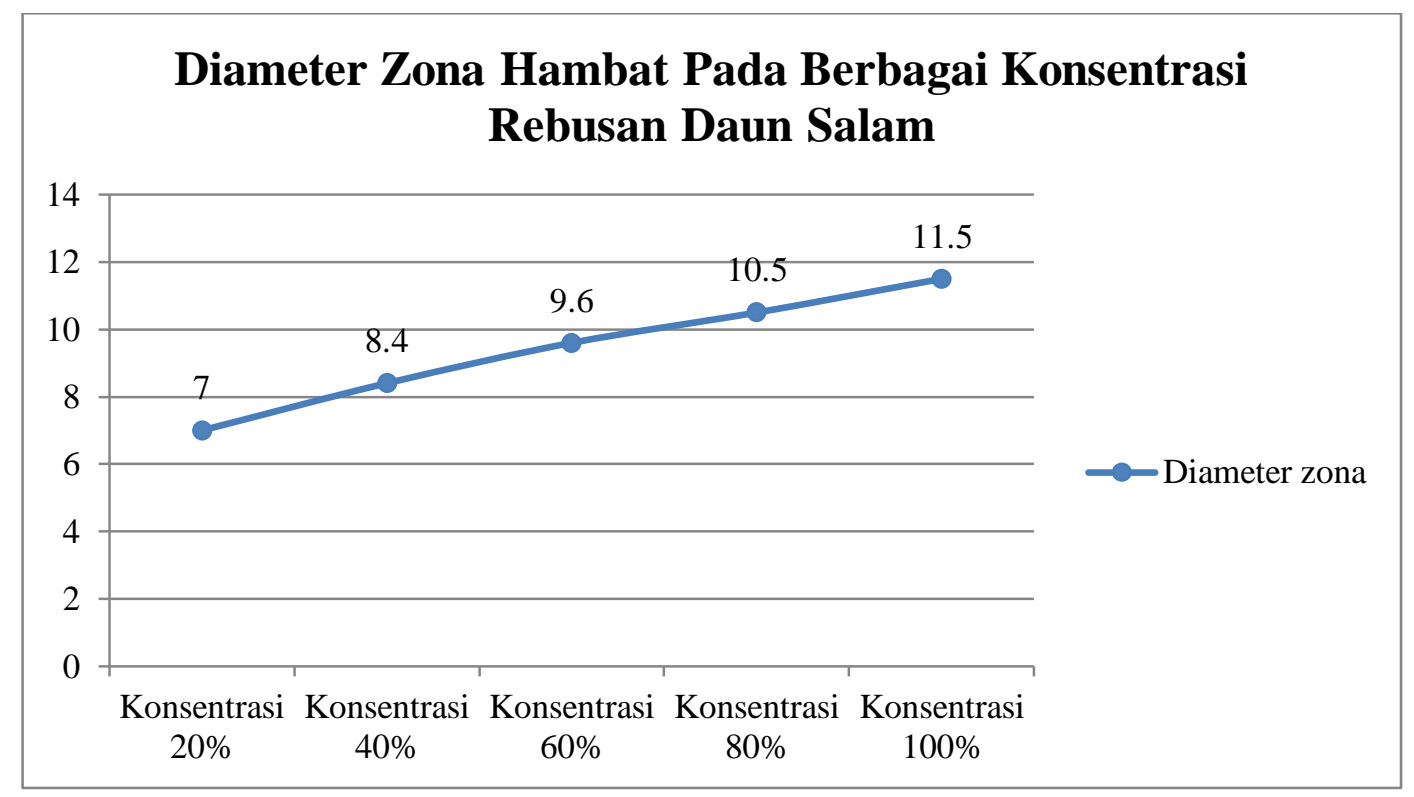

Gambar 1. Perbandingan Zona Hambat Pertumbuhan Bakteri Staphylococcus aureus pada Berbagai Konsentrasi Rebusan Daun Salam (Syzygium polyanthum)

Perbedaan zona terjadi karena adanya kadar zat aktif yang berbeda-beda dari setiap konsentrasi yang dipengaruhi oleh seri pengenceran. Semakin banyak zat aktif yang dilarutkan maka semakin besar diameter zona hambat yang terbentuk, hal ini juga disebabkan oleh adanya kandungan zat aktif seperti minyak atsiri, sitral, eugenol, tanin, dan flavonoid ${ }^{9}$. Berdasarkan fungsi dari kandungan zat 
Luh Kadek Suciari, dkk., Perbedaan Zona Hambat Pertumbuhan Staphylococcus aureus Pada

Berbagai Konsentrasi Rebusan Daun Salam (Syzygium polyanthum) Secara In Vitro

aktif daun salam, sitral mampu menurunkan $\mathrm{pH}$ sitoplasma yang dapat menghambat pertumbuhan bakteri ${ }^{15}$. Eugenol memiliki kemampuan yang dapat mengurangi produksi toksin dari bakteri Staphylococcus aureus sehingga menghambat pertumbuhan ${ }^{16}$. Menurut Pelczar dan Chan flavonoid mempu mendenaturasikan protein sel ${ }^{17}$. Disamping itu adanya kandungan tanin memiliki mekanisme menghambat pertumbuhan bakteri dengan memunculkan denaturasi protein dan menurunkan tegangan permukaan, sehingga permeabilitas bakteri meningkat serta menghambat produksi enzim, dan menganggu proses reaksi enzimatis pada bakteri Staphylococcus aureus sehingga menghambat terjadinya koagulasi plasma yang diperlukan oleh Staphylococcus aureus ${ }^{14}$. Selain sitral, eugenol, flavonoid, dan tanin, juga terdapat kandungan minyak atsiri, namun kandungan minyak atsiri ini tidak larut dalam air sebagai pelarut yang digunakan.Konsentrasi $100 \%$ dalam penelitian ini merupakan konsentrasi tertinggi dari kelima konsentrasi lainnya yang menghasilkan diameter zona hambat terpanjang dan memiliki kemampuan terbesar untuk menghambat pertumbuhan bakteri Staphylococcus aureus.

SIMPULAN DAN SARAN

1. Simpulan
Berdasarkan uraian diatas dapat disimpulkan rerata diameter zona hambat pertumbuhan Staphylococcus aureus pada masing-masing rebusan daun salam (Syzygium polyanthum) konsentrasi 20\%, $40 \%, 60 \%, 80 \%$, dan $100 \%$ berturut-turut sebesar $7 \mathrm{~mm}, 8,4 \mathrm{~mm}, 9,6 \mathrm{~mm}, 10,5 \mathrm{~mm}$, dan $11,5 \mathrm{~mm}$. Diameter zona hambat yang terbentuk memiliki perbedaan yang significant antara diameter zona hambat pertumbuhan bakteri Staphylococcus aureus pada konsentrasi 20\%, 40\%, 60\%, $80 \%$, dan $100 \%$ (nilai $p<0,05$ ), dan konsentrasi $100 \%$ pada penelitian ini menunjukkan diameter zona hambat terpanjang dan merupakan konsentrasi yang paling efektif dari kelima konsentrasi yang diuji dalam menghambat pertumbuhan Staphylococcus aureus.

\section{Saran}

Bagi masyarakat disarankan untuk memanfaatkan rebusan daun salam (Syzygium polyantum) dalammenangani infeksi yang disebabkan oleh Staphylococcus aureusseperti gatal dan bisul pada kulit dengan mengompres permukaan kulit yang mengalami infeksi.Serta bagi peneliti berikutnya perludilakukan penelitian lebih lanjut untuk mengetahui pengaruh zat aktif yang paling dominan dalam menghambat pertumbuhan

Staphylococcus aureus.Selain itu penelitian mengenai 
Luh Kadek Suciari, dkk., Perbedaan Zona Hambat Pertumbuhan Staphylococcus aureus Pada Berbagai Konsentrasi Rebusan Daun Salam (Syzygium polyanthum) Secara In Vitro

pemanfaatanrebusan daun salam lebih

dikembangkan dengan melakukan

pengujian pada bakteri jenis lain sehingga

dapat diketahui manfaat untuk

menghambat infeksi bakteri jenis lainnya.

\section{DAFTAR PUSTAKA}

1. Kementerian Kesehatan RI Direktorat Jenderal Pengendalian Penyakit dan Penyehatan Lingkungan. 2011. Pedoman Pengendalian Infeksi Saluran Pernapasan Akut - 616.24 ind pKesehatan RI. 2011

2. Kementerian Kesehatan RI. 2013. Riset Kesehatan Dasar 2013. http://www.depkes.go.id/resources/download/ general/Hasil\%20Riskesdas\%202013.pdf. diakses 20 Januari 2017

3. Dinas Kesehatan Provinsi Bali. 2015. Profil Kesehatan Provinsi Bali Tahun 2014. http://www.depkes.go.id/resources/download/ profil/PROFIL_KES_PROVINSI_2014/17_B ali_2014. pdf. diakses tanggal 25 November 2016

4. Misnadiarly. 2008. Penyakit Infeksi Saluran Napas Pneumonia pada Amak, Orang Dewasa, Usia Lanjut, Pneumonia Atipik \& Pneumonia Atypik Mycrobacterium. Jakarta: Pustaka Obor Populer

5. Radji, M. 2011. Buku Ajar Mikrobiologi Panduan Mahasiswa Farmasi dan Kedokteran. Jakarta: Penerbit Buku Kedokteran EGC.

6. Jawetz, Melnick, Adelberg. 2014.Mikrobiologi Kedokteran (Medical Microbiology Edisi 25 (diterjemahkan oleh Aryanditho, dkk). Jakarta: Buku Kedokteran EGC

7. Negara, K. S. 2014. Analisis Implementasi Kebijakan Penggunaan Antibiotika Rasional Untuk Mencegah Resistensi Antibiotika di RSUP Sanglah Denpasar: Studi Kasus Infeksi Methicillin ResistantStaphylococcus aureus. Jurnal ASRI.I(1): 42-50.

8. Wiliarni, W. 2016. Uji Resistensi Staphylococcus aureus Dari Pasien Infeksi Kulit di Rumah Sakit Siloam Karawaci Tangerang Banten Terhadap Oksasilin, Vankomisin, Klindamisin, dan Levofloksasin. http://ejournal.uhamka.ac.id/files/disk1/4/univ ersitas\%20muhammadiyah\%20prof.dr.hamka --wellywilia-197-1-jurnalw-).pdf. diakses tanggal 27 Desember 2016

9. Tammi, A.2016. Perbandingan Daya Hambat Ekstrak Daun Salam (Syzygium polyanthum [Wight.] Walp.) Terhadap Pertumbuhan Bakteri Staphylococcus aureus Dan
Escherichia coli Secara In Vitro. Skripsi. Universitas Lampung

10. Notoatmodjo, S. 2012. Metodologi Penelitian Kesehatan, Edisi Rivisi, Cetakan Kedua. Jakarta: Rineka Cipta

11. Herbie, T. 2015. Kitab Tanaman Berkhasiat Obat 226 Tumbuhan Obat untuk Penyembuhan Penyakit dan Kebugaran Tubuh. Yogyakarta: Octopus

12. Dewanti, S., Wahyudi, M. Teguh. 2011. Uji Aktivitas Antimikroba Infusum Daun Salam (Folia Syzygium Polyanthum Wight) Terhadap Pertumbuhan Bakteri Escherichia Coli Secara In-Vitro. Jurnal Medika. Planta Vol. 1 No. 4. Oktober 2011

13. Adrianto, A.W.D. 2012. Uji Daya Antibakteri Ekstrak Daun Salam (Eugenia polyantha Wight) Dalam Pasta Gigi Terhadap Pertumbuhan Streptococcus mutans. Skripsi. Universitas Jember

14. Dani, I.W., Kiki N., Cut F.Z. t.t. Penghambatan Pertumbuhan Aspergillus flavus Dan Fusarium moniliforme Oleh Ekstrak Salam (Eugenia polyantha) Dan Kunyit (Curcuma domestica). https://jurnal.usu.ac.id/index.php/sbiologi/arti cle/view/608/410. diakses 24 Juli 2017

15. Sudirman, T. A. 2014. Uji Efektivitas Ekstrak Daun Salam (Eugenia olyantha) Terhadap Pertumbuhan Staphylococcus aureus Secara In Vitro.Skripsi. Universitas Hasanuddin

16. Bhaskara, G. Y. 2012. Uji Daya Antifungi Ekstrak Etanol Daun Salam (Syzygium polianthum [Wight] Walp.) Terhadap Candida albicans ATCC 10231 Secara In Vitro.

http://eprints.ums.ac.id/22008/11/11._naskah_ publikasi. pdf. diakses tanggal 7 Pebruari 2017

17. Chao S. 2016. Antimicrobial Activity and Possible Mechanism of Action of Citral against Cronobacter sakazakii. http://journals.plos.org/plosone/article?id= 10.1371/journal.pone.0159006. diakses tanggal 7 Pebruari 2017 